"This is the peer reviewed version of the following article: Yunusa, I. A. M., Eamus, D., Taylor, D., Whitley, R., Gwenzi, W., Palmer, A. R. and Li, Z. (2015), Partitioning of turbulent flux reveals contrasting cooling potential for woody vegetation and grassland during heat waves. Q.J.R. Meteorol. Soc..

which has been published in final form at doi: 10.1002/qj.2539 This article may be used for non-commercial purposes in accordance with Wiley Terms and Conditions for Self-Archiving." 


\section{Partitioning of turbulent flux reveals contrasting cooling potential for woody \\ vegetation and grassland during heat waves}

Running title: Turbulent flux over grassland and woody vegetation covers

Isa A. M. Yunusa, ${ }^{a *}$ Derek Eamus, ${ }^{b, f}$ Daniel Taylor, ${ }^{b}$ Rhys Whitley, ${ }^{c}$ Willis Gwenzi, ${ }^{\mathrm{d}}$ Anthony R.

$$
\text { Palmer, }{ }^{\mathrm{e}} \text { Zheng Li, }
$$

${ }^{\mathrm{a}}$ School of Environmental \& Rural Sciences, University of New England, Armidale NSW 2350, Australia

${ }^{\mathrm{b}}$ School of Life Sciences University of Technology, Sydney, Broadway NSW 2007, Australia

${ }^{\mathrm{c}}$ Department of Biology, Macquarie University, NSW 2109, Australia

${ }^{\mathrm{d}}$ Soil Science \& Agricultural Engineering, University of Zimbabwe, P. O. Box MP167 Mount Pleasant, Harare, Zimbabwe

${ }^{\mathrm{e}}$ Centre for African Conservation Ecology, Nelson Mandela Metropolitan University, PO Box 77000, Port Elizabeth 4000, South Africa

${ }^{\mathrm{f}}$ National Centre for Groundwater Research and Training, University of Technology, Sydney, PO Box 123, NSW 2007 Australia

*Correspondence to I. Yunusa, SERS, UNE, Armidale NSW2351, Australia. Email: isa.yunusa@une.edu.au

\section{Abstract}

We compared the capacity of woody versus grassy vegetation covers to buffer high temperatures during heat waves by partitioning turbulent heat between latent $(\lambda E)$ and sensible $(H)$ fluxes, and quantifying advection using the Priestley-Taylor coefficient $(\alpha)$, for a16-year old grassland and an adjoining 6-year old plantation of mixed woody species. We found that because $\lambda E$ 
24 dominated $(>65 \%)$ the turbulent flux in the plantation, and was at least twice as large as on the 25 grassland on which $\lambda E$ was a small percentage $(<35 \%)$ of the turbulent flux during heat waves,

26 the ambient temperature over the plantation was up to $5{ }^{\circ} \mathrm{C}$ lower in the afternoon, and averaged

27 about $1.2{ }^{\circ} \mathrm{C}$ for the whole day, compared with the grassland. Both vegetation covers emitted

28 significant amounts of $H$ that was a source of advective energy when soil-water availability was

29 limited, and also in winter when canopy was mostly inactive because of dormancy in the

30 grassland and mutual shading in the plantation due to low solar angle; advection of additional

31 energy from surrounding vegetation suppressed $\lambda E$ and reduced $\alpha$ to $<1.0$ in both vegetation

32 covers in winter. Advection enhanced $\lambda E$ during periods of frequent rainfalls in summer with

33 mean $\alpha$ rising to 2.6 in the grassland and 3.4 in the plantation. Consistently low $\lambda E$ but high $H$

34 made the grassland a source rather than a sink for advective energy, while the plantation was the

35 opposite. The broadleaved evergreen woody vegetation consistently maintained a larger $\lambda E$ than

36 the grassland in this mid-latitude environment, contrary to the smaller $\lambda E$ observed over mostly

37 coniferous forests at high (northern) latitudes $\left(>35^{\circ}\right)$. Annual evapotranspiration from the

38 grassland $(384 \mathrm{~mm})$ was only $46 \%$ that from the plantation. Woody vegetation covers dominated

39 by broadleaved-species are therefore preferred for buffering extreme high temperatures during

40 heat waves, and recommended for land rehabilitation in populated landscapes. We also

41 developed functions to approximate $\alpha$ for conditions when soil-water availability is limiting.

42 Key words: advection; Bowen ratio; evapotranspiration; heat wave; land-use change; Priestley-

43 Taylor coefficient; sensible heat

Turbulent flux over grassland and plantation 


\subsection{Introduction}

45 Maintaining suitable vegetation types can provide relief from heat stress by buffering extreme

46 temperatures during heat waves or periods of excessively hot weather. Although the World

47 Meteorological Organisation defines heat waves as periods during which daily maximum

48 temperature on five consecutive days exceed the normal (1961-1990) average by $5{ }^{\circ} \mathrm{C}$ (Frich et

49 al., 2002), individual countries adopt their own threshold. For southern coastal cities in

50 Australian, heat wave is any "five consecutive days with maximum temperature at or above 35

$51{ }^{\circ} \mathrm{C}$ or three consecutive days at or above $40{ }^{\circ} \mathrm{C} "$ (Nairn and Fawcett, 2013). The frequency and

52 severity of heat waves have been increasing and projected to intensify with adverse impacts on

53 ecosystems and community welfare. Heat waves have become more frequent with climate-

54 change and associated with increasing mortalities in human (Tong et al., 2010) and avian

55 (McKechnie et al., 2010) populations, and in forests that are correlated with amplified temperatures and atmospheric dryness across forested continents (Allen et al 2010;-Eamus et al.

57 2013). Heat waves also impose enormous demand on power supply for cooling, which can be

58 significantly alleviated by planting trees to provide evaporative cooling (Sawka et al., 2013). The relative efficacy of woody vegetation compared with grassy vegetation covers in

60 providing respite from high temperature stress during heat waves has lately been questioned

61 (Teuling et al., 2010). The severity of the impact of heat waves on ecosystems and human

62 communities depends on how net radiant energy $\left(\mathrm{R}_{\mathrm{n}}\right)$ receipt at the land surface is dissipated

63 between the two forms of turbulent heat transfer: f latent $(\lambda E)$ and sensible $(H)$ heat fluxes:

$64 \quad R_{n}=\lambda E+H+G+S$ 
65 in which $G$ is the ground heat flux and $S$ is the heat tied up in the biological processes of

66 photosynthesis and respiration and is generally considered to be negligible at daily time-scales.

67 In terrestrial ecosystems the relative magnitude of either $\lambda E$ or $H$ depends on the availability of

68 soil-water and the type and condition of the vegetation cover. Hence, maintaining large $\lambda E$

69 relative to $H$ requires access to extractable supply of soil water.

When soil-water is limiting turbulent flux tends to be biased towards $H$ at the expense of

$71 \lambda E$, because of the hydraulic limitation along the soil-plant continuum (Prior and Eamus, 2000)

72 and the high atmospheric demand for water. Therefore vegetation types that retain active

73 canopies, coupled with deep and extensive root systems, generally have a greater capacity to

74 sustain larger rates of $\lambda E$, thereby dampening the severity of heat waves compared to vegetation

75 types that have seasonal growth and shallow root systems (Moore, 1976). Annual

76 evapotranspiration for woody vegetation can range from $15 \%$ to up to a factor of three larger

77 than for grasslands in cool sub-temperate and temperate environments (Eugster and Cattin, 2007;

78 Yunusa et al., 2010b; Yunusa et al., 2012), and by more than 60\% in the tropics (Priante-Filho et

79 al., 2004; Waterloo et al., 1999). A larger canopy cover and a deeper, more extensive root

80 system allows woody vegetation to sustain larger $\lambda E$ compared to grasses in arid environments

81 and during hot and dry periods (Yunusa et al., 2012). Hence it is expected that advective

82 enhancement of $\lambda E$ is limited over grasslands compared with woodlands, especially during heat

83 waves.

The foregoing reasoning contradicts several recent studies that reported larger $\lambda E$ for 85 grasslands than from forest vegetation covers, mostly at high $\left(>35^{\circ}\right)$ latitudes (Baldocchi et al., 86 2004; Rost and Mayer, 2006; Teuling et al., 2010). An analysis of historical data coupled with 
87 more recent measurements in northern Europe by Teuling et al. (2010) found forests to have smaller $\lambda E$, but larger $H$, than the grasslands despite the former having larger and deeper root systems. The authors argued that a strong stomatal control of transpiration in trees during unusually hot periods make forest conservative water-users. Rost and Mayer (2006) earlier reported $\lambda E$ to be $10 \%$ lower from Scotts pine (Pinus sylvestris) compared with nearby grassland. Both the woody and grassy vegetation in these studies had similar accessibility to soilwater supply such that differences in the soil-water was less than $10 \%$ between forests/woodlands and the grasses in the studies of Roberts et al. (2005) in the United Kingdom and that of Baldocchi et al. (2004) in the United States. As a result the woody vegetation generated more $H$, but lower $\lambda E$, compared with the grassland during hot and dry periods when

97 water-supply was limited (Baldocchi et al., 2004; Teuling et al., 2010). Also the differences in the leaf area indices between the grassland and the woody vegetation were often small, in some cases as little as 0.5 (Baldocchi et al., 2004). Many of the forests and/or woodland in these studies were often dominated by, or contain a considerable proportion of, conifers. These are known for their high canopy resistance compared with broadleaved species (Wilson et al., 2002) or grasslands (Kelliher et al., 1993). Under these conditions therefore, the turbulent flux from grasslands would be dominated more by $\lambda E$, and likely to benefit more from advection of 104 additional energy than the conifer dominated woody vegetation. Contributions of advection on $\lambda E$ arising from transient and periodic changes in soil-water and meteorological dynamics can be analysed using evaporation coefficient $(\alpha)$ in the equation of Priestley and Taylor (1972). Land-use change due to economic and/or social activities often results in significant degradation for which rehabilitation commonly involves revegetation to restore ecosystem and 
109 social functions (Eamus et al., 2013; Gwenzi et al., 2012). It is therefore important to consider 110 the capacity of the vegetation in buffering extreme weather conditions to enhance community

111 welfare and to also ensure that vegetation is able to perform the functions required, including

112 dewatering of the soil profile, when choosing vegetation types for rehabilitation in urban and

113 peri-urban environments. In this study we compared surface energy balance for a16-year old

114 grassland and a 6-year old plantation of mixed native evergreen broadleaf woody species

115 established over a rehabilitated waste storage site with shallow groundwater. Our objectives were

116 to (1) apply the $\alpha$ to characterise advective impact on $\lambda E$ from the two vegetation covers, (2)

117 explain how and when latent heat flux can be larger over the plantation than the grassland

118 especially during heat waves, and (3) to close the annual water budget for the two vegetation 119 covers.

\section{$120 \quad 2.0$ Materials and methods}

\section{$121 \quad 2.1$ The site}

122 This study was undertaken at the Waste Management Centre at Castlereagh (33 39' 41" S, $150^{\circ}$

123 46’ 57’ E; $35 \mathrm{~m}$ asl) about 65 km north-west of Sydney’s Central Business District. The site

124 covers approximately 357 hectares with the original soil classified as Chromosol, which is

125 equivalent to Haplic Xerosol (FAO 1974). The soil has a duplex profile consisting of $0.7 \mathrm{~m}$

126 loamy sand topsoil over impermeable heavy clay referred to as Londonderry Clay, which in turn

127 overlays conglomerate sandstone and shales. There are several groundwater systems that

128 fluctuate in height, but the two main ones lay at about $3.0 \mathrm{~m}$ and the other about $17.0 \mathrm{~m}$ from the

129 surface (Yunusa et al., 2010b). Wastes were emplaced into cells (20 m x $5 \mathrm{~m}$, and $5 \mathrm{~m}$ deep)

130 constructed into the clay subsoil and spaced $2 \mathrm{~m}$ apart resulting in approximately 65 cells/ha. The 
131 cells were capped using the excavated soil that was returned in reverse order to provide a soil cap

132 of 2 m over the cells. The reconstructed soil was then planted with either grassy or woody

133 vegetation, and these have been described in detail earlier (Yunusa et al., 2010b; 2012; Morales

134 et al., 2013).

135 The current study involved the grassland and juvenile plantation that were adjacent to

136 each other but separated by a narrow dirt track of about $6 \mathrm{~m}$ (Figure 1). The grassland covered 12

137 ha and was established in 1994 with a mixture of Cynodon dactylon (couch grassland), Axonopus

138 affinis (carpet grassland), Paspalum dilatatum (paspalum), Pennisetum clandestinum and

139 Trifolium repens (white clover). The sward was often allowed to grow to heights of $0.8-1.0 \mathrm{~m}$

140 before being mowed in spring (November) and late winter/early autumn (March/April). The

141 plantation consisted of a 9 ha block established in autumn (April-May) 2004 with a mixture of

142 native trees (mainly Eucalyptus spp, Angophora spp, Casuarina glauca, Melaleuca linariifolia

143 and Syncarpia glommulifera) and shrubs (species of Acacia, Callistemon, Grevillea, Hakea,

144 Kunzea and Leptospermum); these were planted in $5 \mathrm{~m}$ rows that were oriented in northeast -

145 southwest direction. It had an average height of about $4.5 \mathrm{~m}$ at the start of the current study and

146 grew to just over $5.0 \mathrm{~m}$ by mid-2010 when we concluded monitoring.

1472.2 Surface energy balance

148 To quantify advective enhancement or suppression of $\lambda E$ we used the evaporation

149 coefficient $(\alpha)$ in the Priestley-Taylor (1972) equation for determining reference

150 evapotranspiration $\left(E_{o}\right)$ where water supply is not limiting and/or enhanced by advection:

$151 E_{o}=\left[\alpha \frac{s\left(R_{n}-G\right)}{s+\gamma}\right] / \lambda$ 
152 where $s$ is the slope of saturation vapour pressure-temperature curve $\left(\mathrm{kPa}^{\circ} \mathrm{C}^{-1}\right)$ and $\alpha$ is taken as

1531.26 for saturated surfaces in which both aerodynamic and surface resistance are negligible

154 (Priestley and Taylor 1972). When determining actual evapotranspiration on vegetated land

155 surfaces the value for $\alpha$ is lower than the nominal 1.26 when the process is limited by soil-water

156 availability, and is larger than the nominal value when the process is enhanced by advection

157 (Agam et al., 2010; Tabari and Talaee, 2011).

158 Partitioning of net radiation $\left(\mathrm{R}_{\mathrm{n}}\right)$ between its components (eqn 1) was undertaken with Bowen

159 Ratio Energy Balance (BREB) monitoring systems; one system was installed on each of the

160 grassland and plantation sites and the two were separated by a distance of about $450 \mathrm{~m}$ (Figure

161 1). At each location $R_{n}$ was measured at appropriate heights over the vegetation (see below),

162 while $\mathrm{G}$ was measured with heat plates installed into the soil at 50 and $150 \mathrm{~mm}$ depths. Soil

163 moisture content and temperature were also monitored at the same depths. The $\lambda E$ was

164 calculated as follows:

$165 \lambda E=\frac{R_{n}-G}{1+\beta}$

166 where $\beta$ is calculated as:

$167 \beta=\gamma\left(\frac{\Delta T}{\Delta e}\right)$

168 in which $\gamma$ is the psychrometric constant $\left(0.066 \mathrm{kPa}^{\circ} \mathrm{C}^{-1}\right)$, while $\Delta \mathrm{T}$ and $\Delta \mathrm{e}$ are gradients in

169 temperature $\left({ }^{\circ} \mathrm{C}\right)$ and vapour pressure $(\mathrm{kPa})$ between the two measurement heights over the 170 respective vegetation covers. 
The two measurement heights for $T$ and $e$ were $1.2 \mathrm{~m}$ and $1.6 \mathrm{~m}$ over the grass, and

172 initially 5.0 and $6.0 \mathrm{~m}$ over the plantation but were later raised to 5.5 and $6.5 \mathrm{~m}$ due to tree

173 growth. All the sensors and the masts were supplied together as a package (Campbell Scientific,

174 Logan, USA). The remaining term $(H)$ in eqn 1 was obtained as residual, assuming $\mathrm{S}=0$. The

175 setup at both locations provided sufficient fetch: height ratio of at least 21:1 to the north of the

176 BREB unit on the plantation and was more than the minimum of 20:1 recommended for a range

177 of tall vegetation covers (Heilman et al., 1989). Each pair of sensors over the two vegetation

178 covers was mostly within the boundary layers above the respective canopies, which was taken as

1790.13 times the canopy height (Monteith and Unsworth, 1990).

An automatic weather station was installed on the grassland to monitor ambient weather 181 conditions comprising solar radiation $\left(\mathrm{R}_{\mathrm{s}}\right)$, temperature, humidity, wind speed at $1.5 \mathrm{~m}$ height in 182 addition to rainfall and soil-water content at 0.10 and $0.30 \mathrm{~m}$ depths. The evaporative demand for 183 the site was calculated as $\mathrm{E}_{\mathrm{o}}$ using eqn 2. Soil-water was also measured each month to a depth of 184 six meters with a neutron probe using pre-installed aluminum access tube and since reported 185 (Yunusa et al., 2012). Fraction of available soil water $\left(f_{w a}\right)$ was calculated for the topsoil (top 0.3 186 m layer) as follows:

$187 \quad f_{w a}=\left(\frac{S_{t}-S_{w}}{S_{f}-S_{w}}\right)$

188 in which $S$ storage of soil water with subscripts denoting its amounts at time of measurement $(t)$ 189 or permanent wilting $(w)$ or field capacity $(f)$; for this soil $\mathrm{S}_{\mathrm{w}}$ was 0.158 and $\mathrm{S}_{\mathrm{f}}$ was 0.434 190 (Yunusa et al., 2012). 
192 the grassland and data logging commenced immediately at 20 min intervals. Technical problems

193 forced a premature termination of monitoring on the grassland in mid-January 2010 following a

194 lightning strike, but monitoring on the plantation was concluded in April in 2010.

$195 \quad 2.3$ Quantifying advective effects on the energy balance

196 The $\alpha$ for non-saturated surfaces $\left(\alpha^{\prime}\right)$ can be calculated by combining eqns 2 and 3:

$197 \quad \alpha^{\prime}=\frac{s+\gamma}{s(1+\beta)}$

198 The $\alpha^{\prime}$ thus accounts for the effects of soil-water availability, especially soil drying, on surface

199 resistance. From eqn 2 the energy driven fraction of observed latent heat flux $\left(\lambda E_{\mathrm{eo}}\right)$ was

200 determined as: $\lambda E_{e o}=\lambda E / \alpha^{\prime}$. Hence the proportion of $\lambda E$ due to advection $(\% A d v)$ was obtained

201 as:

$202 \% A d v=\left[\frac{\lambda E-\lambda E_{e o}}{\lambda E}\right] \cdot 100$

\subsection{Energy balance during heat waves}

204 The mean maximum daily temperature between 1961 and 1990 for the Hawkesbury district 205 during late spring/summer was $26.9{ }^{\circ} \mathrm{C}$ in November, $28.9{ }^{\circ} \mathrm{C}$ in December and $29.4{ }^{\circ} \mathrm{C}$ in 206 January (Australian Bureau of Meteorology, www.bom.gov.au). These were much lower than 207 observed during the two heat waves in this study of $29.9-37.1{ }^{\circ} \mathrm{C}$ (median of $36.2{ }^{\circ} \mathrm{C}$ ) in late 2082009 (November $21-27)$ and $30.1-40.1{ }^{\circ} \mathrm{C}\left(35.6{ }^{\circ} \mathrm{C}\right)$ in early 2010 (January 9-13). These two 209 periods were compared with a cool period of July 27-August 2, 2009, when maximum 210 temperature range was $15.6-18.8^{\circ} \mathrm{C}$. 


\section{$211 \quad 3.0$ RESULTS AND DISCUSSION}

2123.1 Weather conditions and latent heat flux

213 Weather conditions during the one-year study period were typical of a mild temperate climate

214 (Figure 2a, b) with the mean maximum temperature rising from around $17{ }^{\circ} \mathrm{C}$ in winter (June -

215 August) to highs of around $32{ }^{\circ} \mathrm{C}$ in summer (December-February) during which two heat waves

216 were identifiable in November and January. Trends in minimum temperature and evaporative

217 demand followed a similar pattern with the latter increasing from around $2.0 \mathrm{~mm} \mathrm{~d}^{-1}$ to $6.0 \mathrm{~mm}$

$218 \mathrm{~d}^{-1}$. The first half of the study period was relatively dry with only a few rainfall events that

219 exceeded $10 \mathrm{~mm}$, but the second half was relatively wet with many large rainfall events $(>10$

$220 \mathrm{~mm}$ ) during January-March 2010. The variability in rainfall distribution was reflected in the

221 availability of soil moisture, with the topsoil being drier in the grassland than plantation, but this

222 trend was reversed in the subsoil.

223 Daily $\lambda E$ from both vegetation covers increased as the conditions became warmer from

224 winter through spring (September - November) to summer (Figure 2e). Flux of $\lambda E$ was always

225 lower from the grassland than from the plantation with the difference increasing by as much as a

226 factor of 3 as the season became warmer in summer. This was because (a) the leaf area index

227 was larger for the plantation (mean of 3.2) than the grassland (mean 2.01), and (b) the amount of

228 roots in the grassland was just $40 \%$ that of the plantation (Yunusa et al., 2012). Consequently

229 large amounts of soil-water remained unused in the grassland under which the soil was

230 consistently wetter than the plantation (Figure $2 \mathrm{~d}$ ).

2313.2 Trends in the calculated Priestley-Taylor coefficient and $\lambda E$

Turbulent flux over grassland and plantation 
232 Except during winter to early spring period when it was lower, $\alpha^{\prime}$ remained well above 1.26 for

233 both vegetation covers, reaching maxima in November/December (Figure $2 \mathrm{f}$ ). The $\alpha^{\prime}<1.26$ in

234 winter suggested advective suppression of $\lambda E$ due to stomatal closure during a substantial part of

235 the day. A similar situation occurred with the plantation during cloudy and humid conditions in

236 April/May 2010. At all times $\alpha^{\prime}$ was larger for the plantation than the grassland despite $\mathrm{R}_{\mathrm{n}}$ being

237 mostly lower for the plantation than the grassland (Figure $3 a$ ). The higher $\mathrm{R}_{\mathrm{n}}$ over the grassland

238 compared with the plantation was contrary to expectation since the oft-reported higher albedo

239 from grassland would lower $\mathrm{R}_{\mathrm{n}}$ compared with woody vegetation (Moore, 1976; Teuling et al.,

240 2010). It is not clear why $R_{n}$ was lower for the plantation, but Waterloo et al. (1999) reported

241 albedo for a 6-year old regenerating forest, similar to our plantation site, to be up to $30 \%$ (13\% vs

$24210 \%$ ) smaller than for a mature 15 -year old pine forest, while albedo could be up to $56 \%$ higher

243 from the pine forest than from the grassland. Mowing the grassy groundcover, which constituted

244 at least half of the land area in the plantation, in November, thus caused rapid declines in $\Delta R_{\mathrm{n}}$.

245 Similarly, Wilson et al. (2002) recorded higher $\mathrm{R}_{\mathrm{n}}$ for grassland compared with woody

246 vegetation at several sites.

247

A combination of limited soil-water supply, winter dormancy and occasional mowing

248 suppressed $\lambda E$ from the grassland such that the air above the canopy was warmer, by more than

$249 \quad 1.0^{\circ} \mathrm{C}$ on several occasions, when compared with that above the plantation (Figure 3b). During

250 periods of frequent rainfall (November-January) the difference in temperature between the two

251 vegetation covers was negligible. A trend in the difference in vapour pressure deficit between

252 grassland and plantation $(\Delta D)$ showed that the air above the grassland was always drier than that

253 over the plantation. A moist surface within the plantation increased partitioning of turbulent flux

Turbulent flux over grassland and plantation 
254 through $\lambda E$ resulting in higher $\alpha$ than in the grassland. Diurnal $\alpha$ values for the plantation $(0.8-$

255 3.6) and for the grassland (0.6 -2.6) were consistent with observations in several previous studies

256 that found $\alpha$ to be positively correlated with soil-water supply, and ranging in value from $<0.9$ to

257 >4.5 (Jury and Tanner, 1976; Flint and Childs, 1991; Li and Yu, 2007).

258 In the plantation, the correlations between $\alpha^{\prime}$ and both $\mathrm{G}$ and soil temperature was

259 positive, but was negative with water availability $\left(f_{w a}\right)$ and $H$ (Figure 4 ) suggesting that a

260 substantial fraction of the advected energy was generated locally, especially in this vegetation

261 cover. No such correlations between $\alpha^{\prime}$ and either $G$ or $H$ were observed on the grassland where

262 the topsoil, which contains more than $60 \%$ of the roots, was relatively dry for prolonged periods

263 (Figure 2c). The drying soil in both vegetation covers heated the overlying air to generate $H$ as a

264 local source of advection consistent with a high correlation between $\alpha^{\prime}$ and air temperature in the

265 two vegetation covers (Figure 5a).

2663.3 Interrelationships between fluxes in the grassland and plantation

267 Several components of the energy dynamics over the grassland were correlated with $\lambda E$ over the

268 plantation. For example, $\alpha^{\prime}$ for the two vegetation cover-types were highly correlated with each

269 other, while $\lambda E$ over the plantation held a significant relationship with both $G$ and $H$ over the

270 grassland (Figure 5). This suggested that heat transfer from the grassland to the plantation was

271 driven by the warmer air over the former, especially under the northerly winds that crossed the

272 grassland toward the plantation during this period (Figure 1). Kochendorfer and Paw U (2011)

273 showed that horizontal advection is especially strong and enhanced $\lambda E$ by up to $15 \%$ over a tall

274 and transpiring canopy when the prevailing wind crossed a low-lying and senescing canopy.

275 Similarly, wind mediated enhancement of sensible heat advection from dry surrounding fields

Turbulent flux over grassland and plantation 
276 increased transpiration by nearly $70 \%$ over a tree belt (Hernandez-Santana et al., 2011) and by

$27750 \%$ over irrigated wheat ( $\mathrm{Li}$ and $\mathrm{Yu}, 2007)$.

278 3.4 Diurnal trends in energy fluxes during heatwaves

279 Figure 6 compares diurnal trends in heat fluxes during non-heat wave days in August with two 280 heat wave days for the two vegetation cover-types. The $R_{n}$ increased by more than a factor of 2.5

281 during the heat wave compared with non-heat wave days, and was mostly expended (62-70\%) as

$282 H$ from the grassland; grassland $H$ was three times as large as that that emitted from the

283 plantation where $\lambda E$ accounted for $58-72 \%$ of incoming energy. On the grassland, $\lambda E$ was

284 always smaller than, and lagged behind, $\mathrm{R}_{\mathrm{n}}$ in the morning. In contrast, $\mathrm{R}_{\mathrm{n}}$ and $\lambda E$ were in

285 tandem in the early morning until $0900 \mathrm{~h}$, after which $\lambda E$ declined rapidly and stopped almost

286 entirely by $1400 \mathrm{~h}$. This was likely a consequence of the low zenith angle of the sun $\left(<36^{\circ}\right)$ that

287 declined rapidly as the sun moved northwestwards, shading the southern half of the tree canopy

288 and resulted in gradual stomatal closure of the canopy leaves. Furthermore, the northern half of

289 the canopy would have experienced mutual shading and this feature was tested by approximating

290 the shadow length $(L)$ for the tree rows using the following (Shettigara and Sumerling, 1998):

$291 \quad L=\frac{h}{\tan \Theta}$

292 in which $h$ is row height and $\Theta$ is the angle between horizon and the sun. This equation yielded a

293 shadow length of at least $10 \mathrm{~m}$ around midday, extending to $17 \mathrm{~m}$ by $1600 \mathrm{~h}$, which was large

294 enough to cast shadows onto the canopy rows located to the south.

295 The majority of the incident $\mathrm{R}_{\mathrm{n}}$ from midday onwards was therefore emitted as $H$, even 296 exceeding the magnitude attained by $\lambda E$ earlier in the day. This was despite the high $f_{w a}$ and low 
$D$ at this time (Table 1). The impact of limited incident energy receipt by the canopy was less severe on the plantation compared with the low laying grass that was also dormant at this time so that $94 \%$ total turbulent flux $(\lambda E+\mathrm{H})$ was mainly $H$.

During the heat waves in summer the sun was close to its zenith and the day length was longer. Any stomatal restraint on $\lambda E$ was primarily associated with dryness of the air and not with $f_{w a}$, because the subsoil was quite moist on the two heat wave days (Figure $\left.2 \mathrm{~d}\right) . \mathrm{A} \lambda E /\left(\mathrm{R}_{\mathrm{n}^{-}}\right.$ G) of 0.66 on November 21 and 0.80 on January 13 (Figure 6) indicated a constraint on $\lambda E$ most likely due to a high $D$ that was twice as large on November 21 as on January 13 (Table 1). Conversely the warming potential of the plantation $\left(H /\left(\mathrm{R}_{\mathrm{n}}-\mathrm{G}\right)\right)$ of 0.34 and 0.20 on the two heat wave days, was much smaller than 0.77 and 0.68 for the grassland and was reflected in the differences in air temperature above the two vegetation covers. Notwithstanding the adequate soil-water supply, a limitation in the hydraulic capacity of the plants likely triggered stomatal closure in the woody species of the plantation as a response to high $D$ and temperature (Eamus $e t$ al., 2008; Whitley et al, 2013; Yunusa et al., 2010a). Thus transpiration has been observed to virtually cease in two common Euclayptus spp when temperatures $>30{ }^{\circ} \mathrm{C}$ or $D>2.5 \mathrm{kPa}$ (Yunusa et al., 2010a). Despite this $\lambda E$ over the plantation was 65 and $85 \%$ of the turbulent flux compared to 33 and $35 \%$ over the grassland on the two heat wave days. It was also probable that the plantation accessed the groundwater during this study, unlike in the previous years when the root system was still shallow (Yunusa et al., 2011).

Majority of the $H$ in the plantation emanated from the understorey of mixed pasture groundcover, which accounted for at least half the land area but a small fraction $\lambda E$ in the plantation. Assuming a similar constraint to evapotranspiration from the pasture groundcover in 
319 the plantation as in the grassland, the maximum $\lambda E$ contributed by the understorey groundcover

$320\left(\lambda E_{\text {cov }}\right)$ in the plantation can be approximated from the $\lambda E / \mathrm{R}_{\mathrm{n}}$ of the grassland and the $\mathrm{R}_{\mathrm{n}}$ of the

321 plantation $\left(\mathrm{R}_{\mathrm{n}, \mathrm{pl}}\right)$ as:

$322 \lambda E_{\mathrm{cov}}=\left(\frac{\lambda E_{g l} f_{A} R_{n, g l}}{R_{n, p l}}\right)$

323 where $f_{A}$ is the fractional land area covered by the understorey (taken to be 0.5 ) in the plantation, 324 subscript $g l$ represents grassland and $p l$ plantation. This produced $\lambda E_{\mathrm{cov}}$ values of $0.05,1.28$ and $3251.77 \mathrm{MJ} / \mathrm{m}^{2}$ on representative days in August, November and December (Figure 6) respectively. 326 Therefore the the trees that directly intercepted $\leq 50 \%$ of the incident $\mathrm{R}_{\mathrm{n}}$, contributed was $32798 \%$ of $\lambda E$ in winter (August) and about $74 \%$ during the heat waves in summer. The additional 328 energy for $\lambda E$ from the trees was supplied by advection mostly from the underlying pasture 329 groundcover. Water needed to sustain enhanced transpiration by the trees was most probably 330 extracted from the shallowest water table. Reductions in ambient temperatures arising from 331 enhanced $\lambda E$ and negligible $H$ over woody shrubs with access to a water table were reported by 332 Kustas et al. (1989) for Owens Valley, USA $\left(36^{\circ} 48^{\prime} \mathrm{N} 118^{\circ} 121^{\prime} \mathrm{W}\right)$. The $\lambda E_{\text {cov }}$ fraction was 333 particularly low in summer when the grass component of the pasture was dormant. However, 334 instead of the $H$ emanating from the pasture groundcover being given to warm up the 335 surrounding air it was used to contribute to $\lambda E$ from the trees in the plantation and thereby 336 cooling the surrounding air mass. Differences between the grassland and plantation presented here were unlike those found 338 in similar comparisons between grassland and forest dominated by, or containing a considerable 339 proportion of, conifers at high (northern) latitudes (Teuling et al., 2010). In that study the lower 
$\lambda E$ over grassland/crop compared with the forests was attributed to daytime stomatal restriction

341 of transpiration in the woody species by the prevailing high $D$. A similar situation probably

342 prevailed at Bremgarten $\left(47^{\circ} 54^{\prime} \mathrm{N}, 7^{\circ} 37^{\prime} \mathrm{E}\right)$ in Germany, where $\lambda E$ was always larger, while $H$

343 was smaller, from grassland than from a nearby pine forest (Rost and Mayer, 2006). Our site was

344 at a lower latitude $\left(33^{\circ} 39^{\prime} 41^{\prime}\right.$ S) and the plantation was dominated by broadleaved evergreen

345 woody species that would generally have lower canopy resistance than conifers (Kelliher et al.,

346 1993; Wilson et al. 2002). At the high latitudes $\left(>45^{\circ} \mathrm{N}\right)$ limitations imposed by reduced energy

347 supply (compared to our site) is likely to have a greater impact on the coniferous forests.

Conditions at our mid-latitude sub-temperate environment were closer to those of

349 Mediterranean climate where $\beta$ and surface resistance tend to be relatively small because of

350 proximity to seas/oceans, and advection is common (Wilson et al., 2002). In general, $\beta$ tends to

351 be higher for deciduous and coniferous forests and grasses than for evergreen woody vegetation

352 (Wilson et al., 2002). A small contribution of $H$ to turbulent flux in the plantation thus

353 minimized heat input into the surrounding air mass, which was cooler by as much $4{ }^{\circ} \mathrm{C}$, and more

354 humid, when compared with over the grassland during the days that experienced heat waves

355 (Figure 7).

$356 \quad 3.5$ Diurnal patterns of advection

357 The pattern of advection to $\lambda E$ in both vegetation cover-types changed during the day (Figure 8).

358 In winter advection generally suppressed $\lambda E$ both at night and during the day, except for a brief

359 period around midday when there was an enhancement. As discussed above, it is likely that the

360 stomates shut early in the day during winter as a consequence of low solar elevation and a

361 shorter photoperiod. However, during both heat wave days in summer, advection enhanced $\lambda \mathrm{E}$

Turbulent flux over grassland and plantation 
362 and was more pronounced in the plantation, where it accounted for $>50 \%$ of $\lambda E$. Furthermore, $\beta$

363 in the plantation declined, while that in the grassland increased, and were consistent with the

364 higher $\lambda E /\left(\mathrm{R}_{\mathrm{n}}-\mathrm{G}\right)$ for the plantation on the heat wave days as discussed above. Advection also

365 enhanced $\lambda E$ in the grassland most of the time, but to a much lesser extent than in the plantation

366 (Figure 8). Whatever energy advected to the grassland was emitted, along with that emitted from

367 within, resulting in large $H$, thereby making the grassland more of a source than a sink for $H$.

368 Percentage suppression/enhancement of $\lambda E$ by advection was within the $-300-+300 \%$ reported

369 for irrigated wheat by $\mathrm{Li}$ and $\mathrm{Yu}(2007)$ and comparable to $-40-+60 \%$ in a tree-belt within a

370 cropped landscape (Smith et al., 1997).

3713.6 Annual water budget

372 To estimate $\lambda E$ for the periods with missing data, $\alpha^{\prime}$ was predicted from $f_{w a}$ and air temperatures

373 using polynomial equations for the two vegetation covers as follows:

374 Grassland: $\alpha^{\prime}=-0.33+0.165 f_{w a}+0.088$ airtemp $\quad \mathrm{r}^{2}=0.59$

375 Plantation: $\alpha^{\prime}=-0.082-0.254 f_{w a}+0.132$ airtemp $\quad r^{2}=0.89$

376 We consider these schemes to be a logical approach since they rely on just two variables that are

377 easily determined to predict $\alpha^{\prime}$ and so were used in eqn 2 to obtain ET. Daily ET for the

378 plantation was generally consistent with an average of $2-4 \mathrm{~mm} \mathrm{~d}^{-1}$ observed earlier in $2007-2008$

379 (Yunusa et al., 2011) despite the trees in the plantation being a year older and their contribution

380 to the composite LAI would have also increased. As discussed above, $\lambda E$ dominated the

381 turbulence flux $(50-80 \%)$ during this study in the mostly dry year compared with $30 \%$ two years

382 previously when rainfall was almost 54\% larger than in the year of the current study (Yunusa et

$383 a l ., 2011)$. This is because the grass/legume pasture groundcover accounted for at least half of

Turbulent flux over grassland and plantation 
384 the land area under the plantation. Although ET from the grassland was almost $17 \%$ less than the 385 total rainfall during the period (Table 2), it exceeded rainfall by $81 \%$ in the plantation that must 386 have accessed shallow groundwater as discussed above. Drainage past the root zone from the 387 grassland occurred predominantly in winter when the grasses were mostly dormant. Using as 388 much of the antecedent soil-water as possible in the spring-summer seasons can increase the 389 storage capacity for the storage of rainfall in winter when ET is low and risk of drainage is 390 higher. This will be especially beneficial under vegetation types that experience seasonal 391 dormancy. Such a system is desirable on landscapes containing buried waste materials that need 392 to be hydrologically isolated and drainage eliminated (Gwenzi et al., 2012; Schneider et al., 393 2012).

\section{$394 \quad 4.0$ Conclusions}

395 Advection exerted a significant influence on the partitioning of turbulent flux $(\lambda E$ and $\mathrm{H})$ from 396 the two vegetation cover-types investigated in this study. Fluctuating values of $\alpha$ showed strong 397 seasonality that reflected the degree of canopy inactivity due to supply of either solar energy or 398 soil-water. The generally low values $(<1.26)$ for $\alpha$ in winter suggested suppression of $\lambda E$ by 399 advection because the canopy was completely inactive in the dormant grassland and partially so 400 in the plantation due to reduced illumination of the canopy throughout much of the photoperiod 401 as a consequence of low solar elevation. Thus $H$ dominated the turbulent flux accounting for $40294 \%$ in the grassland and $66 \%$ in the plantation with this energy emitted as heat to the 403 surrounding air during this cool season. As the daylight hours increased into spring and summer 404 and a break in the dormancy of the grassland occurred, advection generally enhanced $\lambda E$ with $\alpha$ 


\section{Acknowledgment}

422 We acknowledge assistance and support by Mr Peter Lowery, Grant Forest and Janusz Dobrolo, 423 throughout this project, and thank Dr Nicole Grant for technical assistance. We appreciate the 424 advice from Dr Helen Cleugh on data analysis, and anonymous referees for their comments on 425 the previous and final versions of our manuscript. The study was jointly funded by WSN

426 Environmental Solutions and Australian Research Council (LP0669063).

$>1.26$, reaching as high as 2.4 in the grassland and 3.2 in the plantation. During the active growing season in spring-summer $\lambda E$ dominated turbulent flux, especially in the plantation where it accounted for $70 \%$, compared with $34 \%$ in the grassland, during heat waves.

Thus the emission of $H$ as warm air was larger from the grassland with the result that it's local air temperature was warmer by as much as $4{ }^{\circ} \mathrm{C}$ during the day compared with the local air temperature of the plantation. On balance, the plantation was primarily a sink, while the grassland was predominantly a source for advected energy. Contrary to the many examples with coniferous forests in high latitudes of the northern hemisphere, the plantation, which was dominated by broadleaved evergreen woody species, maintained a high rate of water-use that was probably relies in part on the shallow groundwater; consequently the plantation used $81 \%$ more water than rainfall during the one year study period.

Exceedance of rainfall by evapotranspiration (ET) in the plantation shows the difficulty of closing the soil-water balance on landscapes with a water table that is accessible to vegetation. It also provides strong evidence that drainage of water beneath the rooting depth can be reduced and perhaps eliminated by woody species within six year, and thus limiting the risk of contaminating water resources on landscapes with buried wastes and on mined sites. 


\section{$428 \quad$ References}

429 Agam N, Kustas WP, Anderson MC, Norman JM, Colaizzi PD, Howell TA, Prueger JH, Meyers TP, Wilson TB. 2010. Application of the Priestley-Taylor approach in a two-source surface energy balance model. J. Hydrometeorol. 11: 185 -198.

Allen CD, Macalady AK, Chenschouni H, Bachelet D, McDowell N, Vennetier M, et al. 2010. A global overview of drought and heat-induced tree mortality reveals emerging climate change risks for forests. For. Ecol. Manage. 259: 660-684.

Baldocchi DD, Xu L, Kiang N. 2004. How plant functional-type, weather, seasonal drought, and soil physical properties alter water and energy fluxes of an oak-grass savanna and an annual

Eamus D, Yunusa I, Taylor D, Whitley R. 2013. Design of store-release covers to minimize deep drainage in the mining and waste-disposal industries: results from a modeling analyses based on ecophysiological principles. Hydrol. Proc. 27: 3815-3824. doi: 10.1002/hyp.9482. 
Eugster W, Cattin R. 2007. Evapotranspiration and energy flux differences between a forest and a grassland site in the subalpine zone in the Bernese Oberland. Die Erde 138: $333-354$.

Eugster W, Rouse WR, Pielke Sr RA, Mcfadden JP, Baldocchi DD, Kittel TG, Chambers S. 2000. Land-atmosphere energy exchange in Arctic tundra and boreal forest: available data and feedbacks to climate. Global Change Biol. 6: $84-115$.

FAO. 1974. Key to the FAO Soil Units. http://www.fao.org/nr/land/soils/key-to-the-fao-soilunits-1974/en/. Accessed: 02.09.2013.

Flint AL, Childs SW. 1991. Use of the Priestley-Taylor evaporation equation for soil water limited conditions in a small forest clear-cut. Agric. For. Meteorol. 56: 247-260.

Frich A, Alexander LV, Della-Marta P, Gleason B, Haylock AMG, Klein TA, Peterson T. 2002. Observed coherent changes in climatic extremes during the second half of the twentieth century. Climate Res. 19: 193-212. doi:10.3354/cr019193.

Gwenzi W, Veneklaas EJ, Bleby TM, Yunusa IAM, Hinz C. 2012. Transpiration and plant water relations of a recently constructed ecosystem under seasonally dry conditions. Hydrol. Proc. 26: 3281-3292. DOI: 10.1002/hyp.8330.

Heilman JL, Brittin CL, Neale CMU. 1989. Fetch requirements of Bowen ratio measurements of latent and sensible heat fluxes. Agric. For. Meteorol. 44: 261-273.

Hernandez-Santana V, Asbjornsena H, Sauerb T, Isenharta T, Schilling K, Schultza R. 2011. Enhanced transpiration by riparian buffer trees in response to advection in ahumid temperate agricultural landscape. For. Ecol. Manage. 261: 1415-1427.

Jury WA, Tanner CB. 1975. A modification of the Priestley and Taylor evapotranspiration formula. Agron. J. 67: 840-842. 
471 Kelliher FM, Leuning R, Schulze E-D. 1993. Evaporation and canopy characteristics of

$472 \quad$ coniferous forests and grasslands. Oecologia 95: 153-I 63

473 Kochendorfer J, Paw U KT. 2011. Field estimates of scalar advection across a canopy edge.

$474 \quad$ Agric. For. Meteorol. 151: 585-594.

475 Kustas WP, Choudhury BJ, Moran MS, Reginato RJ, Jackson RD, Gay LW, Weaver HL. 1989.

476 Determination of sensible heat flux over sparse canopy using thermal infrared data. Agric.

$477 \quad$ For. Meteorol. 44: 197-216.

478 Li L, Yu Q. 2007. Quantifying the effects of advection on canopy energy budgets and water use 479

480 efficiency in an irrigated wheat field in North China Plain. Agric. Water Manage. 89: 116-

481

McKechnie AE, Wolf BO. 2010. Climate change increases the likelihood of catastrophic avian mortality events during extreme heat waves. Bio. Letters 6: 253-256.

483 Monteith, JL, Unsworth, MH. 1990. Principles of Environmental Physics. Edward Arnold, 484 London.

Moore CJ. 1976. A comparative study of radiation balance above forest and grassland. Q. J. R.

$486 \quad$ Meteorol. Soc. 102: 889-899.

487 Morales PA, Yunusa IAM, Lugg G, Li Z, Gribben P, Eamus D. 2013. Belowground eco488 restoration of a suburban waste-storage landscape: earthworm dynamics in grassland and in 489 a succession of woody vegetation covers. Landscape Urban Plan. 120: 16- 24.

490 Nairn JR, Fawcett RG 2013. Defining heatwaves: heatwave defined as a heat-impact event 491 servicing all community and business sectors in Australia. The Centre for Australian Weather and Climate Research BOM/CSIRO, Australia, Technical Report No 060. 
http://www.cawcr.gov.au/publications/technicalreports/CTR_060.pdf. Accessed: January 5, 2015.

Priante-Filho N, Vourlitis GL, Hayashi MMS, Nogueira JDS, Campelo JH, Nunes PC, Silveira M. 2004. Comparison of the mass and energy exchange of a pasture and a mature transitional tropical forest of the southern Amazon Basin during a seasonal transition. Global Change Biol. 10: 863-876.

Priestley CHB, Taylor RJ. 1972. On the assessment of surface heat flux and evaporation using large-scale parameters. Monthly Weather Rev. 100: 81-92

Prior LD, Eamus D. 2000. Seasonal changes in hydraulic conductance, xylem embolism and leaf area in Eucalyptus tetradonta and Eucalyptus miniata saplings in a north Australian savanna. Plant Cell Environ. 23: 955-965.

Roberts J, Rosier P, Smith DM. 2005. The impact of broadleaved woodland on water resources in lowland UK: II. Evaporation estimates from sensible heat flux measurements over beech woodland and grass on chalk sites in Hampshire. Hydrol. Earth Sys. Sci. 9: 607-613. doi:10.5194/hess-9-607-2005.

Rost J, Mayer H. 2006. Comparative analysis of albedo and surface energy balance of a grassland site and an adjacent Scots pine forest. Climate Res. 30: 227-237.

Sawka M, Millward AA, Mckay J, Sarkovich M. 2013. Growing summer energy conservation through residential tree planting. Landscape Urban Plan. 113: 1-9.

Schneider A, Arnold S, Doley D, Mulligan DR, Baumgartl T. 2012. The importance of plant water use on evapotranspiration covers in semi-arid Australia. Hydrol. Earth Sys. Sci. 9: 
Shettigara VK, Sumerling GM. 1998. Height determination of extended objects using shadows in spot images. Photogramm. Eng. Rem S. 64: 35-44.

Smith DM, Jarvis PG, Odongo JC. 1997. Energy budgets of windbreak canopies in the Sahel. Agric. For. Meteorol. 86: 33-49.

Tabari H, Talaee PH. 2011. Local calibration of the Hargreaves and Priestley-Taylor equations for estimating reference evapotranspiration in arid and cold climates of Iran based on the Penman-Monteith model. J. Hydrol. Eng. 16: 83 -845.

Teuling AJ, Seneviratne SI, Stöckli R, Reichstein M, Moors E, Ciais P, Luyssaert S, van den Hurk B, Ammann C, Bernhofer C, Dellwik E, Gianelle D, Gielen B, Grünwald T, Klumpp K, Montagnani L, Moureaux C, Sottocornola M, Wohlfahrt G. 2010. Contrasting land cover response and heat wave amplification in Europe. Nat. Geosci. 3: $722-727$. doi:10.1038/ngeo950.

Tong S, Ren C, Becker N. 2010. Excess deaths during the 2004 heatwave in Brisbane, Australia. Int. J. Biometeorol. 54: 393-400.

Waterloo MJ, Bruijnzeel LA, Vugts HF, Rawaqa TT. 1999. Evaporation from Pinus caribaea plantations on former grassland soils under maritime tropical conditions. Water Resour. Res. 35: $2133-2144$.

Whitley R, Taylor D, Macinnis-Ng C, Zeppel M, Yunusa I, O’Grady A, Froend R, Medlyn B, Eamus D. 2013. Developing an empirical model of canopy water flux describing the common response of transpiration to solar radiation and VPD across five contrasting woodlands and forests. Hydrol. Proc. 27: 1133-1146.

Wilson KB, Baldocchi DD, Aubinet M, Berbigier P, Bernhofer C, Dolman H, Falge E, Field C, Goldstein A, Granier A, Grelle A, Halldor T, Hollinger D, Katul G, Law BE, Lindroth A, 

Meyers T, Moncrieff J, Monson R, Oechel W, Tenhunen J, Valentini R, Verma S, Vesala T, Wofsy S. 2002. Energy partitioning between latent and sensible heat flux during the warm season at FLUXNET sites. Water Resour. Res. 38: 30-41.

541 Yunusa IAM, Aumann CD, Rab MA, Merrick N, Fisher PD, Eberbach PL, Eamus D. $2010 \mathrm{a}$.

542 Topographical and seasonal trends in transpiration by two co-occurring Eucalyptus species

543 during two contrasting years in a low rainfall environment. Agric. For. Meteorol. 150:

$544 \quad 1234-1244$.

545 Yunusa IAM, Fuentes S, Palmer AR, Macinnis-Ng CMO, Zeppel MJB, Eamus D. 2011. Latent 546 heat fluxes during two contrasting years from a juvenile plantation established over a waste 547 disposal landscape. J. Hydrol. 399: 48-56.

548 Yunusa IAM, Zeppel MJB, Fuentes S, Macinnis-Ng CMO, Palmer AR, Eamus D. 2010b. An 549 assessment of the water budget for contrasting vegetation covers associated with waste 550 management. Hydrol. Proc. 24: 1149-1158.

551 Yunusa IAM, Zolfaghar S, Zeppel MJB, Li Z, Palmer AR, Eamus D. 2012. Fine root biomass 552 and its relationship to evapotranspiration in woody and grassy vegetation covers for 553 ecological restoration of waste storage and mining landscapes. Ecosys. 15: 113-127.

554 
556 Figure 1. Site of study indicating locations of the Bowen Ration Energy Balance (BREB)

557 monitoring towers at Castlereagh, Australia. The years in which the plantations were established 558 are given in parenthesis.

559 Figure 2. Five-day running averages for (a) minimum and maximum temperatures, (b) rainfall 560 for the site, (c) soil-water stored in the topsoil $(0-0.3 \mathrm{~m}),(\mathrm{d})$ soil-water stored in the subsoil, (d) 561 latent heat flux ( $\lambda E)$ from grassland and plantation, and (e) Priestley-Taylor coefficient, observed 562 between 2009 and 2010 at Castlereagh, Australia. The $\mathrm{x}$ in (c) and (f) indicates when the grass 563 was mowed.

564 Figure 3. Five-day running averages for the differences (grassland-plantation) in (a) $\alpha$ or net 565 radiation $\left(\mathrm{R}_{\mathrm{n}}\right)$ and (b) air temperature or vapour pressure deficit $(D)$, between 2009 and 2010 at 566 Castlereagh, Australia. The two heat wave periods are indicated as $H W$ in (b).

567 Figure 4. Regressions of Priestley-Taylor coefficient $(\alpha)$ on fraction of available water $\left(f_{w a}\right)$ in 568 the topsoil (0-0.3 m layer) (a, e), sensible heat flux $(\mathrm{H})(\mathrm{b}, \mathrm{f})$, soil-heat flux $(\mathrm{G})(\mathrm{c}, \mathrm{g})$, and soil 569 temperature (e, h) observed between 2009 and 2010 at Castlereagh, Australia. The top panels are 570 for grassland and bottom panels for the plantation.

571 Figure 5. Relationships between energy exchange variables over grassland and plantation 572 between 2009 and 2010 at Castlereagh, Australia: (a) Priestley-Taylor coefficient ( $\alpha$ ) versus 573 mean air temperature; (b) $\alpha$ for grass versus that for plantation; (c) relationships between latent 574 heat flux $(\lambda E)$ from the plantation with either sensible heat $(H)$ or with $(\mathrm{d})$ ground heat flux $(G)$ 575 from the grassland. The two fitted lines in (a) have a common intercept. 
576 Figure 6. Diurnal fluxes of net radiation ( $R_{n}$, solid line), latent heat ( $\lambda E$, dotted line), sensible 577 heat ( $H$, dashed line) and ground heat ( $G$, dashed-dotted line) observed on August $2(\mathrm{a}, \mathrm{b})$, 578 November 21 (c, d) and January 13 (e, f) over grassland (a, c, e) and plantation (b, d, f) at 579 Castlereagh, Australia. Daily totals $\left(\mathrm{MJ} / \mathrm{m}^{2} / \mathrm{d}\right)$ for the four fluxes are given for each date.

580 Figure 7. Diurnal trends in the differences (grassland-plantation) in (a) temperature, (b) net 581 radiation $\left(R_{n}\right)$ and (c) vapour pressure deficit observed on the three dates at Castlereagh, 582 Australia. Also shown are the base (zero) lines.

583 Figure 8. Percentage contribution of advection to latent heat flux on grassland and plantation on 584 (a) 2 August 2009, (b) 21 November 2009 and (c) 13 January 2010 at Castlereagh, Australia. 


\section{TABLE LEGENDS}

587 Table 1. Daily averages for key meteorological variables over the whole study site or the

588 respective vegetation covers on three selected days at Castlereagh, Australia

589 Table 2. Summary of water balance variables and leaf area index (LAI) for the grassland and 590 plantation covers between July 2009 and June 2010.

591 
592 Table 1. Daily averages for key meteorological variables over the whole study site or the 593 respective vegetation covers on three selected days at Castlereagh, Australia

\begin{tabular}{lllll}
\hline Variables & Vegetation & 2 Aug & 21 Nov & 13 Jan \\
\hline Wind speed $\left(\mathrm{m} \mathrm{s}^{-1}\right)$ & Site & 0.51 & 1.71 & 1.83 \\
Mean wind direction $(\mathrm{deg})$ & Site & 198 & 212 & 174 \\
\%Adv $(\%)$ & Grassland & -79.1 & 24.6 & 45.0 \\
& Plantation & -62.4 & 74.2 & 44.0 \\
Mean $\theta$ & Grassland & 0.28 & 0.14 & 0.15 \\
& Plantation & 0.39 & 0.24 & 0.24 \\
Calculated PT coefficient $\left(\alpha^{\prime}\right)$ & Grassland & 0.71 & 1.76 & 2.01 \\
Mean $\beta$ & Plantation & 0.80 & 3.98 & 3.65 \\
& Grassland & 0.05 & 0.46 & 0.79 \\
Mean vapour pressure deficit $(D, \mathrm{kPa})$ & Grassland & 0.45 & 2.26 & 1.19 \\
& Plantation & 1.66 & 0.10 & -0.26 \\
Mean air temp $\left({ }^{\circ} \mathrm{C}\right)$ & Plantation & 0.43 & 2.15 & 1.07
\end{tabular}


595 Table 2. Summary of water balance variables and leaf area index (LAI) for the grassland and plantation covers between July 2009 and

596 June 2010

\begin{tabular}{lllllll}
\hline Variables & $\begin{array}{l}\text { Vegetation } \\
\text { covers }\end{array}$ & $\begin{array}{l}\text { Feb-Jun ‘09 } \\
\text { (Autumn) }\end{array}$ & $\begin{array}{l}\text { Jun-Sep ‘09 } \\
\text { (Winter) }\end{array}$ & $\begin{array}{l}\text { Sep-Dec ‘09 } \\
\text { (Spring) }\end{array}$ & $\begin{array}{l}\text { Dec 09-Apr ‘10 } \\
\text { (Summer) }\end{array}$ & $\begin{array}{l}\text { Total or } \\
\text { (average) }\end{array}$ \\
\hline Rainfall (mm) & Site & 271 & 49 & 109 & 34 & 463 \\
$\mathrm{E}_{\mathrm{o}}(\mathrm{mm})$ & Site & 257 & 159 & 362 & 440 & 1218 \\
Mean Leaf area index & Grassland & 1.5 & 1.8 & 2.2 & 1.8 & $(1.8)$ \\
(LAI) & Plantation & 2.9 & 3.1 & 3.3 & 2.8 & $(3.0)$ \\
Change in soil-water & Grassland & 39 & -69 & -6 & -20 & 52 \\
storage (mm) & Plantation & 29 & -21 & 10 & -87 & -31 \\
Evapotranspiration & Grassland & 128 & 40 & 112 & 108 & 384 \\
(mm) & Plantation & 195 & 94 & 267 & 282 & 838 \\
Putative drainage & Grassland & 104 & 78 & 3 & -50 & 185 \\
(mm) & Plantation & 47 & -24 & -168 & -161 & 47 \\
\hline
\end{tabular}

I negative values effectively represent zero drainage and are additional water sourced from the groundwater 


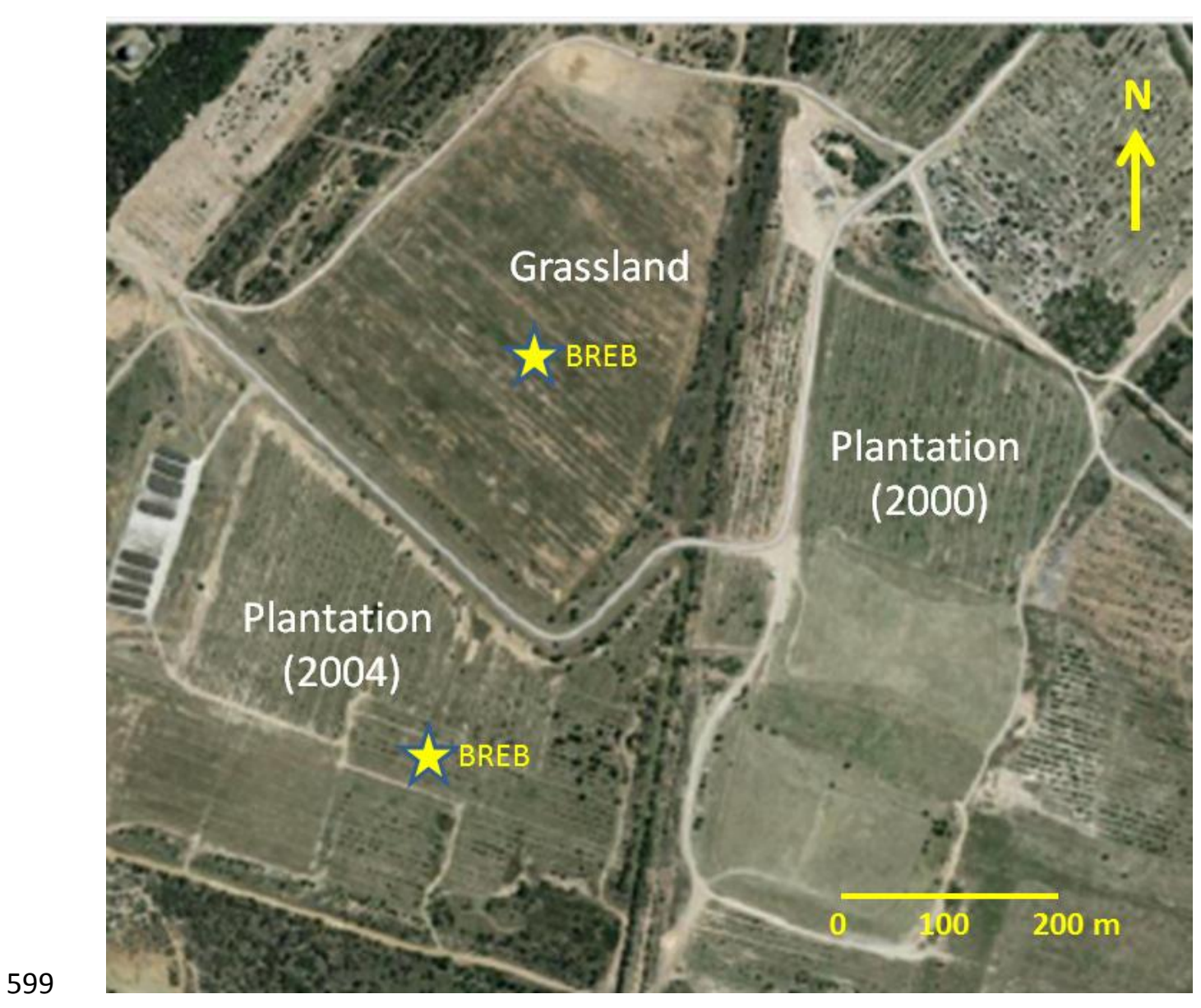

600 Figure. 1. Site of study indicating locations of the Bowen Ration Energy Balance (BREB)

601 monitoring towers at Castlereagh, Australia. The years in which the plantations were established 602 are given in parenthesis. 

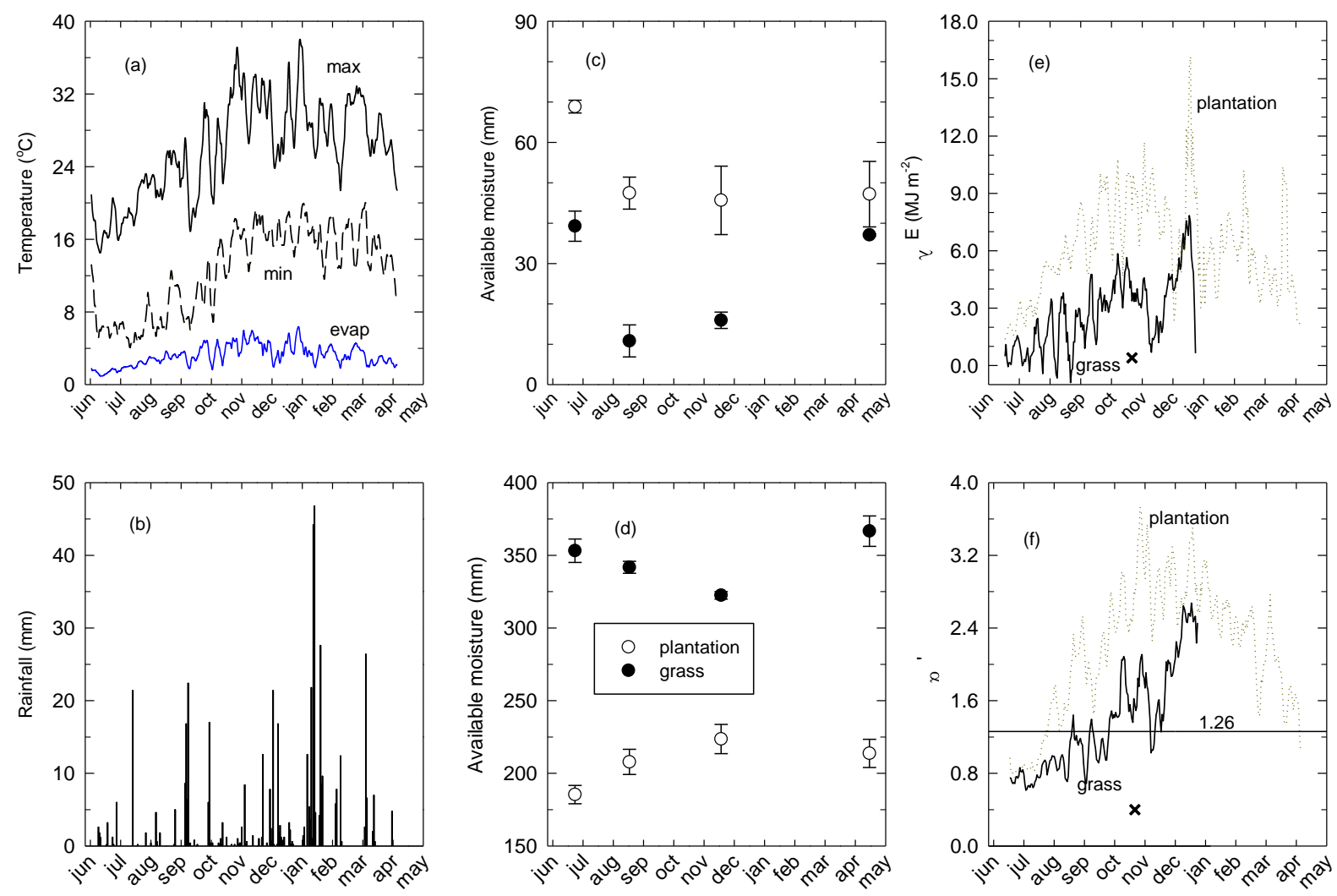

604 $2009--2020$

$2009--2010$

$2009-2010$

605 Figure 2. Five-day running averages for (a) minimum and maximum temperatures, (b) rainfall

606 for the site, (c) soil-water stored in the topsoil $(0-0.3 \mathrm{~m}),(\mathrm{d})$ soil-water stored in the subsoil, (d)

607 latent heat flux ( $\lambda E$ ) from grassland and plantation, and (e) Priestley-Taylor coefficient, observed

608 between 2009 and 2010 at Castlereagh, Australia. The $\mathrm{x}$ in (c) and (f) indicates when the grass was mowed. 

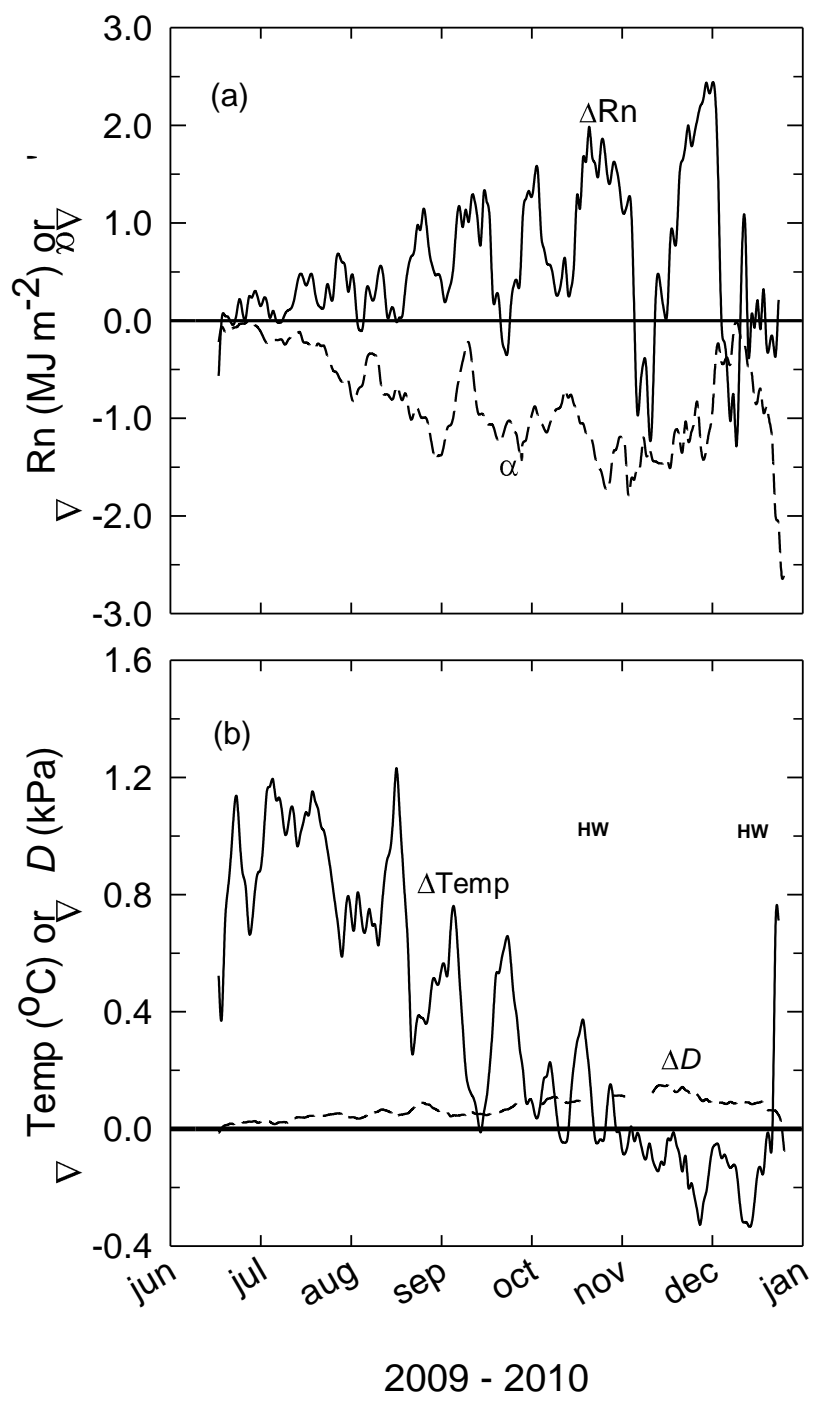

610

611 Figure 3. Five-day running averages for the differences (grassland-plantation) in (a) $\alpha$ or net

612 radiation $\left(\mathrm{R}_{\mathrm{n}}\right)$ and (b) air temperature or vapour pressure deficit $(D)$, between 2009 and 2010 at

613 Castlereagh, Australia. The two heat wave periods are indicated as $H W$ in (b). 

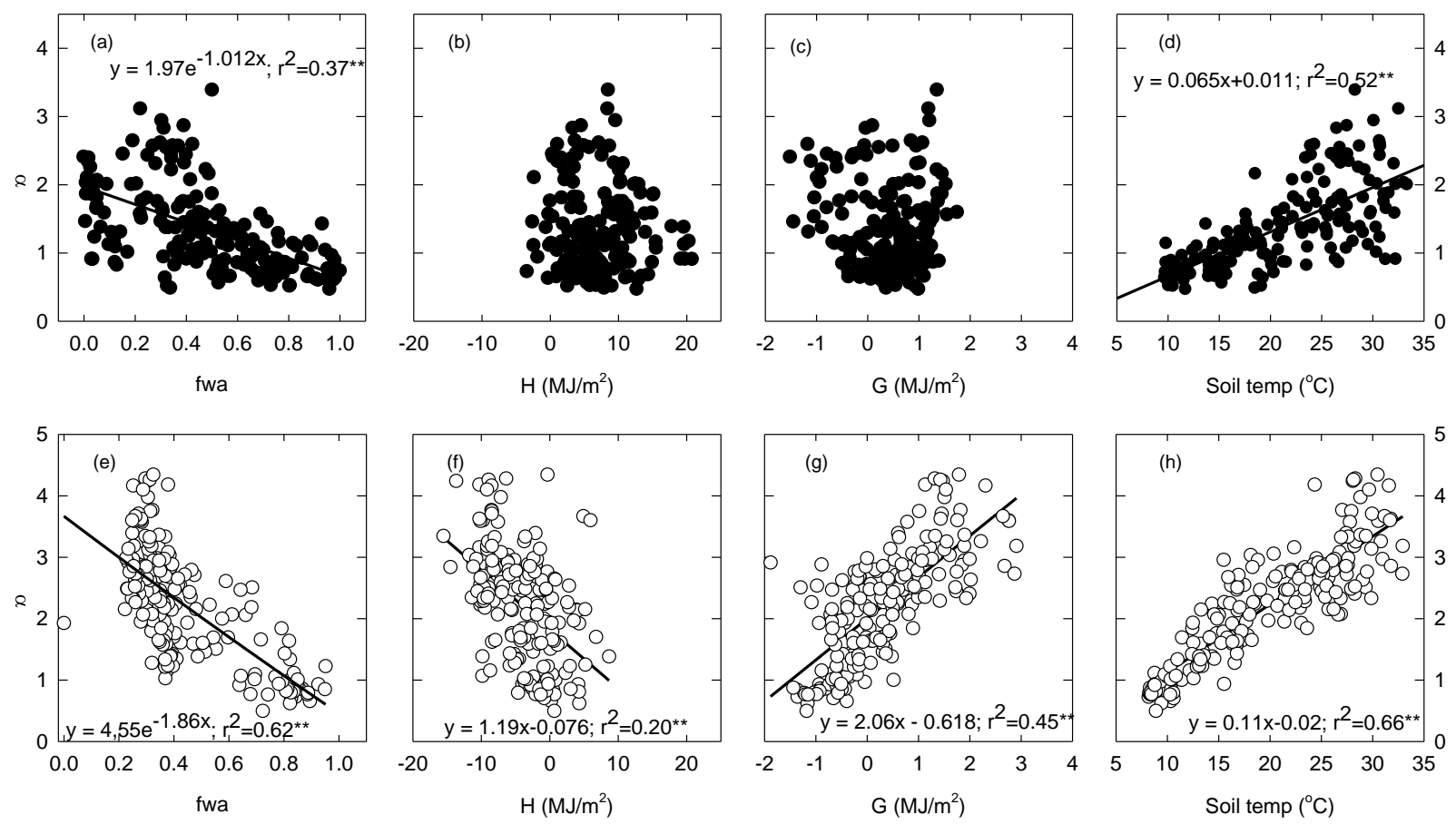

616 Figure 4. Regressions of Priestley-Taylor coefficient ( $\alpha)$ on fraction of available water $\left(f_{w a}\right)$ in

617 the topsoil (0-0.3 m layer) (a, e), sensible heat flux $(H)(b, f)$, soil-heat flux $(G)(c, g)$, and soil

618 temperature (e, h) observed between 2009 and 2010 at Castlereagh, Australia. The top panels are 619 for grassland and bottom panels for the plantation. 

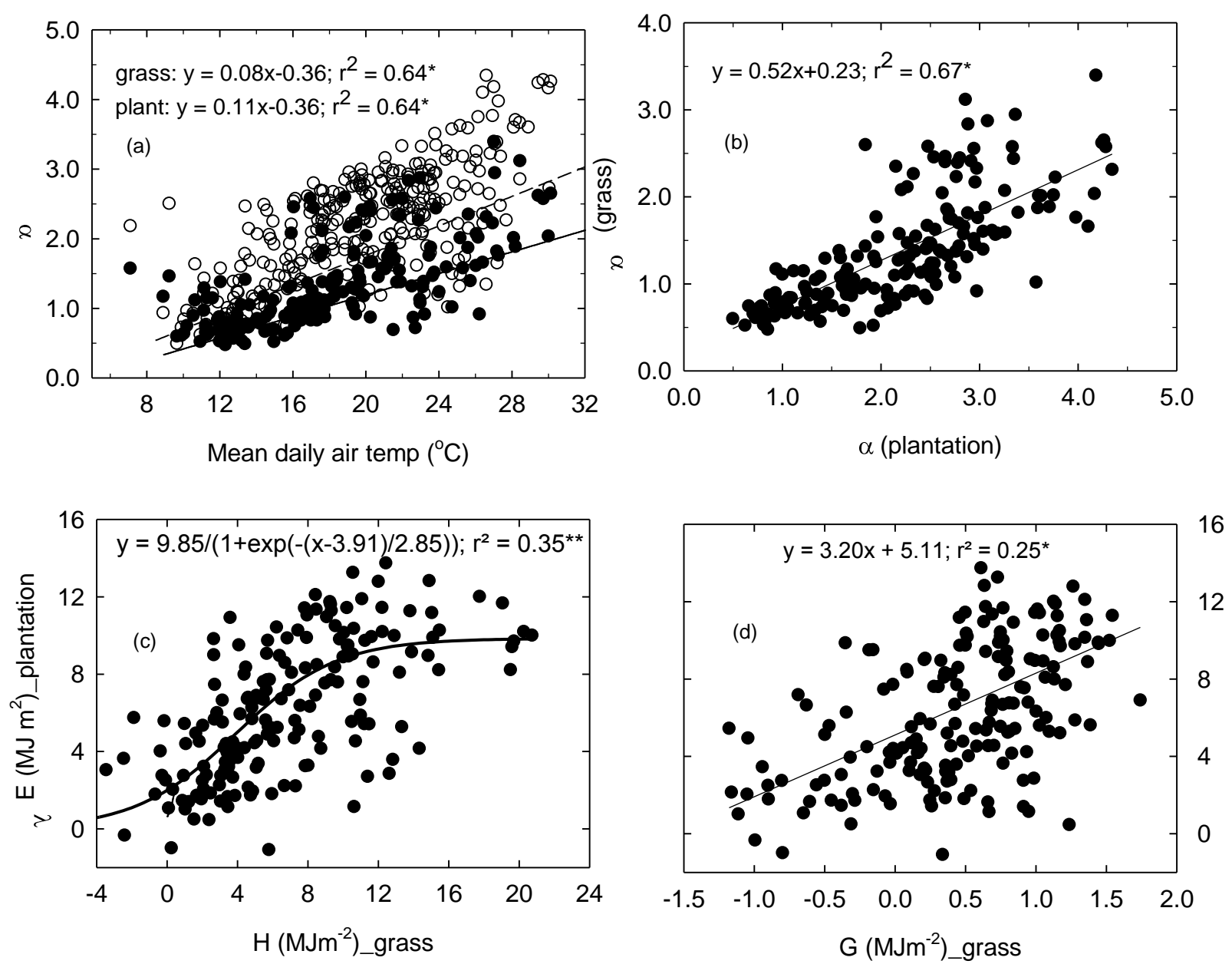

622 Figure 5. Relationships between energy exchange variables over grassland and plantation

623 between 2009 and 2010 at Castlereagh, Australia: (a) Priestley-Taylor coefficient ( $\alpha$ ) versus

624 mean air temperature; (b) $\alpha$ for grass versus that for plantation; (c) relationships between latent

625 heat flux $(\lambda E)$ from the plantation with either sensible heat $(H)$ or with (d) ground heat flux $(G)$

626 from the grassland. The two fitted lines in (a) have a common intercept. 

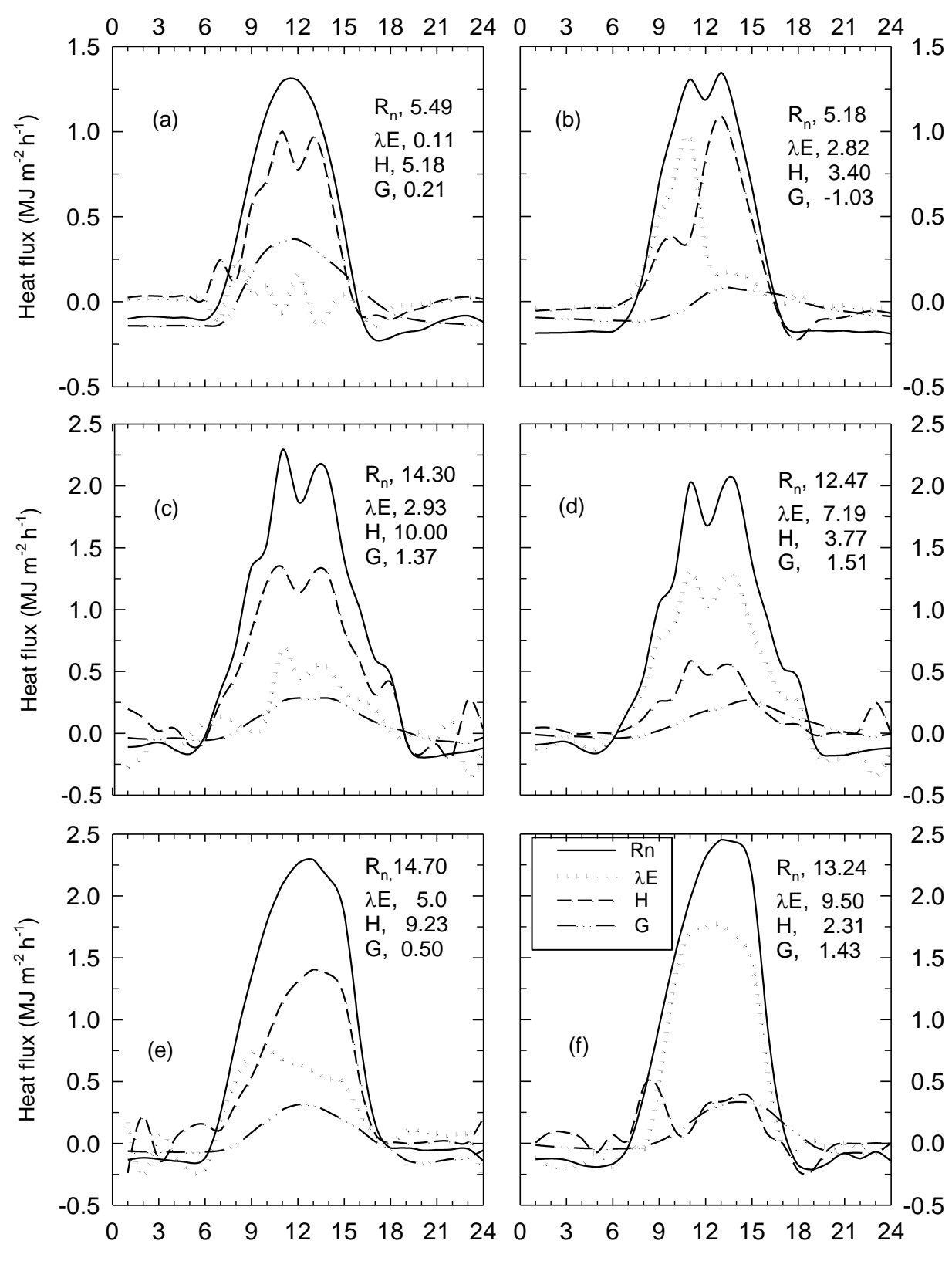

628

Aust Eastern Standard Time

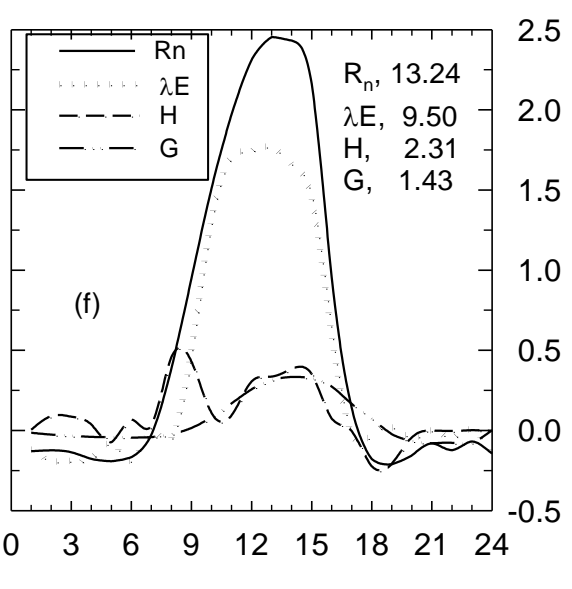

Aust Eastern Standard Time

629 Figure 6. Diurnal fluxes of net radiation $\left(R_{n}\right.$, solid line), latent heat ( $\lambda E$, dotted line), sensible

630 heat ( $H$, dashed line) and ground heat ( $G$, dashed-dotted line) observed on August 2 (a, b),

631 November 21 (c, d) and January 13 (e, f) over grassland (a, c, e) and plantation (b, d, f) at

632 Castlereagh, Australia. Daily totals $\left(\mathrm{MJ} / \mathrm{m}^{2} / \mathrm{d}\right)$ for the four fluxes are given for each date. 

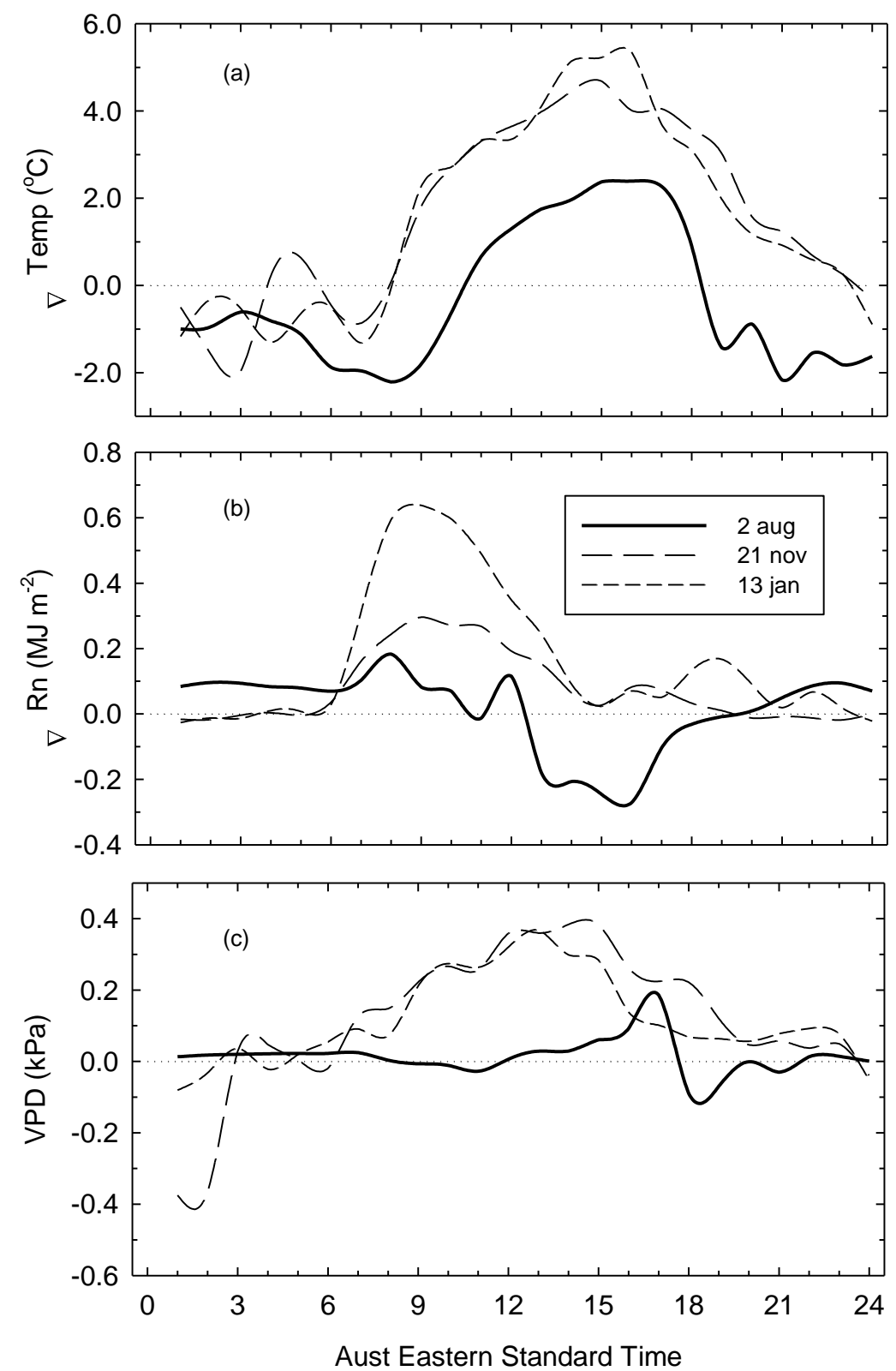

Aust Eastern Standard Time

634 Figure 7. Diurnal trends in the differences (grassland-plantation) in (a) temperature, (b) net 635 radiation $\left(R_{n}\right)$ and (c) vapour pressure deficit observed on the three dates at Castlereagh,

636 Australia. Also shown are the base (zero) lines. 

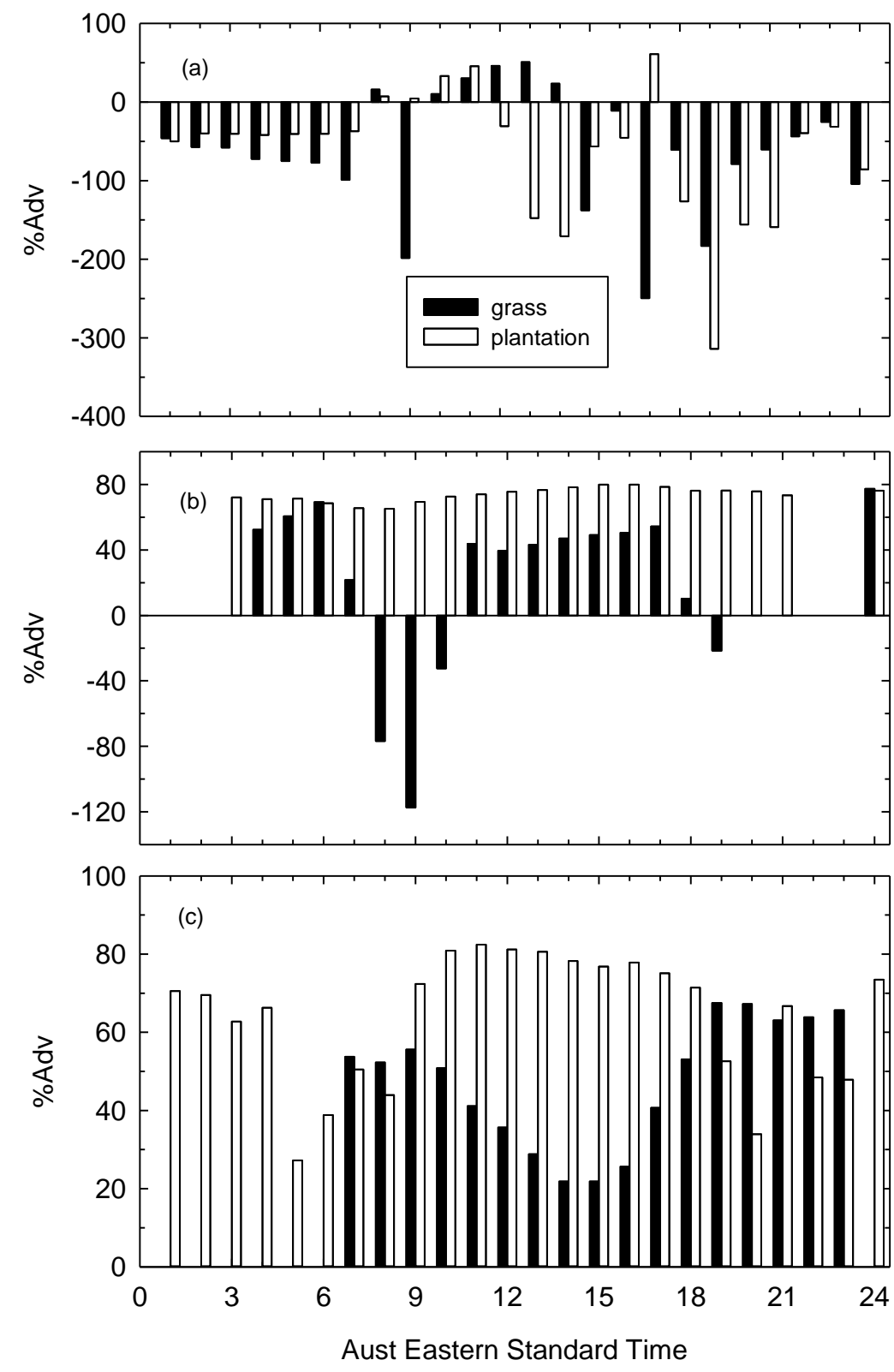

Aust Eastern Standard Time

638 Figure 8. Percentage contribution of advection to latent heat flux on grassland and plantation on 